\title{
Method of Problem Based Learning of Learning in Course Theory on Soft Skills Competence of Students
}

\author{
Cecilia Lelly Kewo ${ }^{1,2, *}$, Ventje Senduk ${ }^{1}$ \\ ${ }^{1}$ Fakultas Ekonomi, ${ }^{2}$ Fakultas Ilmu Pendidikan \\ Universitas Negeri Manado \\ Manado, Indonesia \\ *lellycecilia_kewo@yahoo.com
}

\begin{abstract}
In dealing with the global era with rapid acceleration, it is necessary for workers who not only have the ability to work in their fields (hard competencies), but also very important to master the ability to face change and to use soft competence. Increased skills and skills for prospective workers are the responsibility of the world of education, both formal and non-formal education. Problem Based Learning (PBL) is one of the learning methods that are currently being introduced to be applied in vocational higher education learning systems that are expected to contribute to the achievement of competencies set in theoretical subjects. Research objective consist of 1) to determine the effectiveness of learning methods that are taught to be applied to theoretical subjects. 2) To find out the benefits of the problem based learning method in improving soft skills competence. 3) To determine the impact of problem based learning of learning methods on students' problem solving abilities. This research can be used extensively for theoretical subjects in the Department of Business Administration, Manado State Polytechnic and at the same time provide experience for students who will follow the Field Work Practice program in managing the problems faced in the world of work.
\end{abstract}

Keywords—problem based learning, soft skill, course theory

\section{INTRODUCTION}

The new world order, including the order of the Indonesian economy is changing towards free trade and the global era. But on the other hand, these changes have resulted in increasingly fierce competition in terms of goods, services, capital and labour / human resources. To be able to take part in this era required Human Resources (HR) who have competitiveness openly, adaptive and anticipatory, able to work in teams and ethically, all of which are soft competence (soft skills). Competence can be interpreted in all forms of motives, attitudes, skills, knowledge, behaviour or other personal characteristics, components of competencies are: Knowledge, Skill, Self-Concept, and Traits Motives.

The above description is clear that the role of education in the future is to prepare human resources in the global era that have hard competencies and soft competencies in an integrated manner to be able to think, behave and act creatively. Manado State Polytechnic as one of the higher education institutions has global competence with quality education services. Problem Based Learning (PBL) is one of the learning methods introduced to be applied in vocational higher education learning systems which are expected to be able to contribute to the achievement of competencies set in theoretical courses. It is assumed that PBL learning strategies are integrated as active and constructive learning significantly and can improve the quality of innovation and independent learning.

Based on the above background, the research objectives are to determine the effectiveness of the learning method in the Import Export course. For the benefits of Problem Based Learning Methods in improving the ability of student case analysis in the Department of Business Administration, knowing the achievement of objectives through the Problem Based Learning method of student problem solving skills in the Department of Business Administration. Meanwhile, the benefits of research is able to think critically and solve problems, creativity and innovation, willingness to continue learning, hard work to achieve success and thinking strategies, also provide experience for students who will follow the Field Work Practice program in managing problems faced in the world of work.

\section{LITERATURE REVIEW}

\section{A. Understanding of High-level Thinking of Soft skills}

Soft skills are a new way to explain a number of abilities or talents that are seen when a person works at work James and James cited in Mitchel [1]. In this era of the 21st century, a paradigm shift emerged that strictly the workforce must master more soft skills than hard skills (Ganzel cited in Mitchel [1]). Also learn certain ways that are different from those mastered, learn techniques of thinking to analyse problems, solve problems [2]. High-level thinking skills developed in integrated PBL learning are: critical thinking and problem solving skills, creativity and innovation skills, willingness to continue learning, hard effort to achieve success, thinking strategy. 10 competencies (soft skills) that must be owned by a Leader: Initiative, Leadership, Orientation on Excellent Work Quality, Ability to Solve Problems, Work Planning, Cooperation, Negotiation Skills, Learning Skills, Mentoring and Developing Others, Communication Skills.

\section{B. Problem Based Learning}

Research in various parts of the world has shown the effectiveness of using PBL approaches in this regard are: 
promoting higher-order thinking, knowledge construction, collaborative learning, and independent learning. Similarly, PBL can develop generic skills and attitudes: teamwork, chairing a group, listening, recording, and respect for colleagues' views, rhythm evaluation of literature, self-directed learning and use of resorts, presentation skills. PBL stages as stated by Williams [3] are presented as follows:

Debate professionally using various information, literature, or experience of experts, and concluding learning outcomes are related to problems and practical needs.

\section{Learning Integrated PBL.}

Integrated PBL learning is based on the idea that with an integration pattern it allows subjects to learn to build knowledge holistically through integrated skills where students learn how to analyse the situation, analyse problems, find solutions to solutions and solve problems. With integrated PBL allows students to be able to effectively use knowledge, facts or data to solve problems? With this way allows students to find facts, prove problems, find ideas and solutions and make activity plans? The results of the research show increasing student performance and the emergence of soft skills values examines the effects of problem based learning on soft skills [4]. The integration of soft skills through project-based learning is examined [5]. Examines the integration of soft skills through active learning finding that active learning has fostered soft skills and other skills needed to improve work performance in this 21 st century era realization.

Measurement of leadership performance can increase financial accountability, namely in the financial statements or annual reports. Disclosure of financial reports to external parties / stakeholders will move towards better public accountability. In developing countries, budget management in local governments is usually assessed on government performance. In the context of governance, the process of public participation and the participation of apparatus to create transparency in budget management that is efficient, effective, and professional can encourage performance improvement and financial accountability.

\section{RESEARCH METHODOLOGY}

The student population is 150 people, a sample of 25 people, using simple random sampling, and descriptive analytical research methods. Where the data obtained from observations, interviews, and documentation analysis and field notes is not in the form of numbers. Research is done by multiplying information, looking for relationships to various sources and then comparing and finding results on the basis of actual data. This application is inseparable from the nature of the research carried out namely descriptive research that is explorative [6]. Analysis that is understood in the form of table analysis is then described in accordance with the purpose of this study.

\section{RESULTS AND DISCUSSION}

\section{A. Research Results}

Problem based learning of learning model was obtained from action research with the Export Import course in the study the researcher used two cycles.

1) Report of cycle I: The problem Based Learning (PBL) of Learning Method is carried out with the Import ImportExport Procedure. Steps of cycle I: Planning phase in cycle 1 learning scenarios and learning preparation al. making the Semester Implementation Plan (RPS), subject matter, and posttest, preparing research instruments such as observation sheets and questionnaires.

a) Implementation of action and observation: The implementation of actions based on the RPS is prepared at the planning stage. In cycle I, the implementation of actions can be described as follows: Initial Activity, the researcher wishes to greet the audience to recognize the presence of the student. Delivering material, goals, and the benefits of competencies that will be studied, as well as learning lessons that will be carried out during the learning process provide motivation to students about the benefits of studying import and export.

b) Core activities: Before starting to explain the learning material researchers divided students into four groups. In three groups consisted of 6 people, one group of 7 people. The group division is based on the level of student ability.

c) Final activity: Researchers evaluate and conclude learning outcomes, provide posttest questions as a measure of students' understanding. Motivational learning questionnaire to determine the level of student motivation in following the learning process using the problem based learning method.

d) Reflection: After the action in the form of Problem Based Learning (PBL) method was carried out, reflection was carried out by observing the results of cycle observations and observing the posttest scores of students, for the implementation of cycle II, striving to increase scores for aspects of learning motivation of Import Export which did not meet the criteria of at least $75 \%$ of tenacious aspects face difficulties, enjoy working independently, perseverance on routine tasks, and happy to find and solve problems of problems. Reflections on the second cycle are: The importance of cooperation when doing group assignments. Lecturers involve themselves more to help students achieve maximum results, students are able to do group and individual tasks, conducive learning atmosphere, foster a sense of ability to enjoy learning, give awards to the best individuals and groups in doing the tests given by the lecturer in order to increase students' interest in getting the best score. So that students become motivated in following the learning process.

The results of the data obtained in learning using the problem based learning method in the first cycle are: There are indicators that have not reached the minimum specified criteria, namely tenacious indicators facing difficulties (71.25\%), happy working independently $(69.37 \%)$, perseverance on routine tasks $(74.37 \%)$, and happy to find and solve problem problems 
$(71.75 \%)$. From this data will then be used as one of the reflex material.

2) Report of cycle II: Steps of research carried out in cycle II are to prepare a Semester Learning Plan learning of Export Import course. Prepare observation sheets and questionnaires to determine the success of problem based learning models in cycle II, compile and prepare questions that measure abilities.

a) Implementation of the action: The first cycle action is carried out for two meetings; the first was held on Monday, June 4, 2018 and continued on June 11, 2018.

b) Initial activities: Researchers conduct opening greetings, pray, absent student attendance, make commitments when lessons are taking place, make the learning atmosphere conducive. so that students feel comfortable in the learning process to convince every student that they are able to do the assignments given and are able to make the best results. Give gifts to individuals and groups who get the best values and attitudes.

c) Core activities: Researchers explained again about the chronology of Problem Based Learning of learning to provide mtivation, evaluate the results of investigations. Each group leader takes a lottery topic they will discuss based on the draw they get. Each group gets material about Free Alongside Ship (FAS), Free on board (FOB) and other groups discussing Cost, Insurance and Freight.

d) The final activity: Researchers evaluate and conclude the learning outcomes, give the second session for 45 minutes. Then give a questionnaire. After the students complete the questionnaire the researcher announces the best groups and students in cycle I and II. After that the researcher closed the lesson and gave greetings.

e) Reflection. The results of action research in the first cycle showed an increase in learning achievement and motivation of students. Increased motivation when the learning process has an impact on learning outcomes, $100 \%$ of students get scores more than before. Motivation data and student learning achievement in cycle II can be seen as follows:

Observation Data, Observations using the prepared observation guidelines. Scores on each indicator Motivation to learn Export import reaches minimum criteria of $75 \%$. Overall score of Learning Motivation Export import exceeds the minimum score of $85.19 \%$.

\section{B. Discussion}

Students' Export Import Learning Motivation, Research includes planning, implementing, observing and reflecting. The observation phase shows students' export import learning motivation during Problem Based Learning (PBL) of learning. Cycle 1 and cycle II show activities that reflect an increase in Student Motivation for Export import course. Based on data of increasing scores in learning motivation for Export Import cycle 1 to cycle II, it shows that by applying the Cooperative Learning Method type Problem Based Learning has increased by $9.8 \%$.
TABLE I. COMPARISON OF LEARNING MOTIVATION SCORES FOR IMPORT EXPORTS BASED ON OBSERVATIONS IN CYCLE I AND CYCLE II.

\begin{tabular}{|c|c|c|c|c|}
\hline \multirow{2}{*}{$\begin{array}{c}\text { No } \\
\text {. }\end{array}$} & \multirow[t]{2}{*}{ Indicator } & \multicolumn{2}{|c|}{ Score } & \multirow{2}{*}{$\begin{array}{c}\text { Enhance } \\
\text { ment }\end{array}$} \\
\hline & & Cycle I & Cycle 2 & \\
\hline 1 & Diligently facing the task & $76,25 \%$ & $87,49 \%$ & $11,24 \%$ \\
\hline 2 & $\begin{array}{ll}\text { Resilient } & \text { facing } \\
\text { difficulty }\end{array}$ & $71,75 \%$ & $84,52 \%$ & $12,77 \%$ \\
\hline 3 & Interest in learning & $81,25 \%$ & $86,90 \%$ & $5,64 \%$ \\
\hline 4 & $\begin{array}{l}\text { Prefer to } \quad \text { work } \\
\text { independently }\end{array}$ & $69,37 \%$ & $83,33 \%$ & $13,96 \%$ \\
\hline 5 & $\begin{array}{l}\text { Persistence on routine } \\
\text { tasks }\end{array}$ & $74,37 \%$ & $83,33 \%$ & $8,96 \%$ \\
\hline 6 & Maintaining opinion & $79,37 \%$ & $85,11 \%$ & $5,74 \%$ \\
\hline 7 & $\begin{array}{l}\text { Not easy to release what } \\
\text { is believed }\end{array}$ & $78,12 \%$ & $85,11 \%$ & $6,99 \%$ \\
\hline 8 & $\begin{array}{l}\text { Prefer to find and solve } \\
\text { problems }\end{array}$ & $71,75 \%$ & $85,71 \%$ & $13,96 \%$ \\
\hline \multicolumn{2}{|c|}{ Average Score } & $75,39 \%$ & $85,19 \%$ & $9,8 \%$ \\
\hline
\end{tabular}

The overall conclusion of the Learning Motivation for Import Export course and the indications that cover it consists of:

1) The indicator of diligently facing the task: There was an increase in cycle I to cycle II of $11.24 \%$. Improved Learning Motivation scores student import exports were also shown from questionnaire data where there was an increase of $8.42 \%$ from the second cycle. In the questionnaire data it increases the score of diligent indicators of facing the task are equally improved and has reached minimum criteria of $75 \%$. In learning using the Problem Based Learning Method, the class becomes more conditioned for students to want to work on the questions given by the lecturer thoroughly.

2) The indicator of resilient facing difficulties: The score in cycle I show that the resilient indicator faces difficulties of only $71.75 \%$, this indicates that the tenacious indicator facing difficulties is still relatively low. Whereas in cycle II indicators faced difficulties increased to $84.52 \%$, this indicates there was an increase of $8.63 \%$. In addition, data from the questionnaire shows that in the first cycle the tenacious indicator faced difficulties of $71.56 \%$ and in the second cycle it increased by $7.6 \%$ to $79.16 \%$. Based on observations made during the learning process from the cycle I and cycle II, it can be seen that in the cycle, some students did not ask the lecturer when experiencing difficulties. Students prefer to ask friends rather than lecturers. This is because students find it easier to understand the material with the language used by their friends when explaining. This is also due to the fact that in the first cycle, the material provided was mostly theoretical and source that students had also covered the material being taught, so that students felt there was no need to ask questions about the material.

3) The indicator of interest in learning: There was an increase in scores on this indicator by $5.64 \%$ from the first cycle to the second cycle. Meanwhile in the questionnaire there was an increase in score of $4.08 \%$. With the implementation of Problem Based Learning of learning is able to provide positive changes to the classroom atmosphere that is built. In this learning process there is a group discussion that 
can create interesting, meaningful and challenging learning so that students have an interest in learning.

4) The indicator of prefer to work independently: On the motivation score that the observer made to the indicator of students prefers to work independently were still quite low, namely only $69.37 \%$ in the cycle I, but an increase of $13.96 \%$ to $83.33 \%$ in the cycle II. The questionnaire data also showed the same thing, namely that in the first cycle the score of student motivation was only $70.41 \%$ not much different from observations made by observers, and increased by $6.17 \%$ in cycle II to $76.58 \%$. This happens because students feel unable to work on their own tasks given by the lecturer to the group so that they only expect their group friends to work, but in cycle II students feel the need to do group work in solving problems in each question given by the lecturer to the group, because the questions are not only in the form of a theory but in the form of a case so that students feel the need to exchange opinions with their group friends so that their work can be easily completed.

5) The indicator of persistence on routine tasks: An increase of $8.9 \%$ occurred from the cycle I to cycle II on the motivation score data conducted by observers. In the cycle I, students have not felt accustomed to doing tasks with a new learning model. However, in cycle II, there was an increase where students felt happy with the learning process carried out in the classroom so that students were more active in carrying out tasks given by the lecturer. This is because the situation and conditions in the classroom are more conducive because all students are more comfortable with the conditions of the teaching and learning process so that they are not easily saturated. From data, it was also found that most students began to pursue problem based learning methods because they were considered more pleasant. In the questionnaire data there was an increase of $3.98 \%$ from cycle I to cycle II. In this data the motivation score had reached the minimum set criteria of $75 \%$. This is because students feel comfortable with group learning situations and exchange ideas.

6) The indicator of maintaining opinions: There was an increase in scores from the cycle I of $5.74 \%$ to cycle II. Judging from the questionnaire data there was also an increase in score of $7.53 \%$. Both data have exceeded the predetermined minimum criteria of $75 \%$. Based on the data obtained during the learning process, it can be seen that basically students have greater confidence in their abilities. This can be seen from the efforts made by students in defending their opinions when exchanging ideas in doing assignments from lecturers. From here, it shows the level of student confidence in maintaining his opinion.

7) The indicator of not easy to release what is believed: A score increase of $6.99 \%$ was obtained from cycle I to cycle II. The increase of the questionnaire data was shown by $2.38 \%$ of the cycle to cycle II. The results on the data that have been obtained indicate that the score obtained has exceeded the minimum criteria that have been determined that is equal to $75 \%$. This is because students feel confident about what they present when there are other groups who argue about the answers made by the group. The existence of a process of mutual objection is when the presentation process is carried out. When the group considers it right while the other groups consider the answer is not correct. In this process the lecturer becomes a liaison between students so that there is a pleasant atmosphere of discussion, the lecturer does not limit what must be answered by students but lecturers giving students the freedom to express their opinions when students feel that what they believe is true. When students feel that they think that their opinions are the right one, this is where the lecturer assigns the right answers so that there is no difference in understanding between students. So that students remain interested in carrying out the learning process carried out.

8) The indicator of prefer to find and solve problems: There was a score increase of $13.96 \%$ from cycle I to cycle II. In the cycle I students are still no interest in doing assignments given by lecturers, students tend to postpone their work and prefer to chat with their friends, but in the cycle II there is an increase in the enthusiasm of students in doing assignments given by lecturers because students feel that they enjoy the learning process that uses the method cooperative learning type problem based learning. So, those students feel like solving more difficult problems when they are able to work on easy questions. In the observation data, questionnaire data also showed an increase in score of $13.12 \%$.

From the discussion of the results of research on Learning Motivation Import export through observation and questionnaire can be concluded that both have increased in each indicator although there are still some who have not met the minimum criteria score that has been determined, especially in cycle I and the difference in scores on both. This is because each student has different opinions so that they cannot force students to choose the answers so that students sometimes choose different answers to what they have done. It is different from observations where researchers together with observers themselves make observations when learning takes place so that the results obtained are more in line with the predetermined indicators. In addition, the time of observation and filling out different questionnaires also influenced the assessment of several indicators of student motivation.

\section{CONCLUSION}

\section{A. Conclusion}

Based on the results and discussion above, it can be concluded that:

- To improve student learning motivation in the Export Import subject by giving an explanation of learning objectives, giving maximum attention to students during the learning process, and giving praise to students and groups who get the best grades, this is obtained through observation with a score of $75,39 \%$

- To improve student learning achievement is done by giving encouragement or motive for achievement, creating conducive learning atmosphere, providing 
material explanation in an easy-to-understand way, directing students' attention while the lesson is taking place.

\section{B. Recommendation}

Lecturers should use a variety of learning methods so as to increase student motivation and learning achievement. It is better to give a greater opportunity to express their opinions to students to take an active role in a learning process.

\section{REFERENCES}

[1] W.G. Mitchel, "Essential Soft Skills for Success in the Twenty-First Century Workforce as Perceived by Business Educators," Delta Pi Epsilon Journal, vol. 52, no, 1

[2] M.R. Gagne, The Conditions of Learning., New York: Holt Rinehart and Winston, 1977

[3] L. Williams and W.T. Barrett, Introduction to Enquiry and Problembased Learning, Dublin: UCD Teaching and Learning, Wood view House, University College Dublin, 2010.

[4] R.C. Walters and T. Sirotiak, "Assessing the effect of project based learning on leadership abilities and communication skills," 47th ASC Annual International Conference Proceedings, 2011.

[5] C. Nealy, "Integrating Soft Skills Through Active Learning In The Management Classroom," Journal of Collage teaching \& learning, vol. 2, no. 4, 2005 .

[6] A. Hakim and S. Kumadji, Pengantar Statistika, Surabaya: CV. Citra Media, 1997. 